\title{
Congenital Mature Cystic Teratoma of the Lateral Neck Presenting as Cystic Hygroma: A Rare Case Report with Literature Review
}

\author{
Boyun Lateralinde Kistik Higromaya Benzer Görünümde Konjenital \\ Matür Kistik Teratom: Olgu Sunumu ve Literatürün Gözden Geçirilmesi
}

\author{
Thin Thin WIN ${ }^{1}$, Nur Hidayati Mohamad FAKARUL RAZY ${ }^{1}$, Suzina Sheikh AB HAMID², \\ Anusha BALASUBRAMANIAN ${ }^{2}$, Ganesh RAMALINGGAM ${ }^{2}$ \\ Department of ${ }^{1}$ Pathology and ${ }^{2}$ Otorhinolaryngology - Head and Neck Surgery, Sains Malaysia University, School of Medical Sciences, KELANTAN, MALAYSIA
}

\section{ABSTRACT}

Teratoma of the neck is a rare extra-gonadal teratoma. Although it can be seen in adult, most of the cases present in fetal life or early childhood. Grading and classification of teratoma is important for management and prognosis. Decision making between mature and immature teratoma is sometime challenging if it is not composed of extensive unusual neuroectodermal tissue component. We reported a rare case of huge congenital mature cystic teratoma composted of various neuroectodermal tissues in an 8-month-old boy; it was located at the lateral neck and mimicked congenital cystic hygroma. A literature review was done to grade and classify the tumour.

Key Words: Teratoma, Immature, Cystic lymphangioma, Head and neck neoplasms

\section{INTRODUCTION}

Teratomas are germ cell tumours that originate in totipotential cells and are composed of tissues arising from more than one germ cell layers (1). They are most commonly located in the sacrococcygeal region, followed by the ovaries, testis, anterior mediastinum, retroperitoneum, and finally the head and neck, which account for less than $5 \%(2,3)$.

Teratoma of the neck is uncommon location. Most of them present as midline involvement and they have relationship with thyroid gland (4). Many congenital cervical teratoma can be mistaken as cystic hygroma (4). We report a rare case of huge congenital mature cystic teratoma in an 8-month-old baby boy; it was located at the lateral neck and mimicked congenital cystic hygroma. Due to some uncommon histological findings, we reviewed the literature to classify and grade the tumour.

(Turk Patoloji Derg 2014, 30:220-224)

Received : 24.10.2013 Accepted : 18.11.2013

\section{ÖZ}

Boynun teratomu ender görülen gonad dışı teratomları arasında yer alır. Erişkinlerde görülebilmesine karşın, olguların çoğu fetal hayatta ya da erken çocuklukta ortaya çıkar. Teratomların derecelendirilmesi ve sınıflandırılması, tedavi ve prognoz için önemlidir. Nöroektodermal komponentin yoğun olmadığı durumda matür ve immatür teratom ayırımı yapmak zordur. Burada 8 aylık bir oğlan çocuğunda, değişik nöroektodermal dokular içeren boyun bölgesinin ender görülen doğumsal dev teratomu sunulmaktadır. Boynun lateralinde lokalize bu tümör doğumsal kistik higromayı taklit etmekte idi. Tümör derecelendirmesi ve sınıflandırması için literatür taraması yapıldı.

Anahtar Sözcükler: Teratom, İmmatür, Kistik lenfanjioma, Baş boyun tümörleri
An 8-month-old boy was admitted to head and neck surgical unit with huge cystic left lateral neck mass presented since birth. The mass was clinically diagnosed as cystic hygroma. The cystic mass was noticed since antenatal period and the baby was delivered via elective caesarean section. The mass was very huge and bigger than the baby's head. However, there were no breathing difficulties and the baby was able to suck well without chocking. Weight gain was normal. Imaging findings also suggested cystic hygroma and it was treated with sclerotherapy 3 times. However, the cystic mass failed to reduce in size. At the age of 8 months, surgical excision was planned after Magnetic Resonance Imaging (MRI) scan was performed. MRI showed mixed intensity with mainly fluid component (Figure 1). Intra-operatively, huge cystic mass was seen at the left neck region extending from the left ear lobe to the left supraclavicular region

Correspondence: Thin Thin WIN

Sains Malaysia University, School of Medical Sciences, Department of

Pathology, KELANTAN, MALAYSIA

E-mail: safiya@kb.usm.my Phone: +60 97676445 
inferiorly and cervical vertebra posteriorly. It also extended intra-orally and caused thinning of buccal mucosa. It measured $14 \times 18 \mathrm{~cm}$ in diameter. After aspiration of 5.4 liters of straw color fluid, the mass was excised. Few enlarged lymph nodes measuring around $1 \times 1 \mathrm{~cm}$ were seen at the left parapharyngeal area and were also excised. All the specimens were sent for histopathological examination.

On gross pathological examination, it was a cystic mass measuring $15 \times 12 \times 6 \mathrm{~cm}$ in diameter and $5-8 \mathrm{~mm}$ in wall thickness. It contained yellowish gelatinous material. Serial cut sections showed partly solid and partly cystic with variegated appearance. Solid areas measured about $3 \times 4 \times 3$ $\mathrm{cm}$ in diameter (Figure 2).

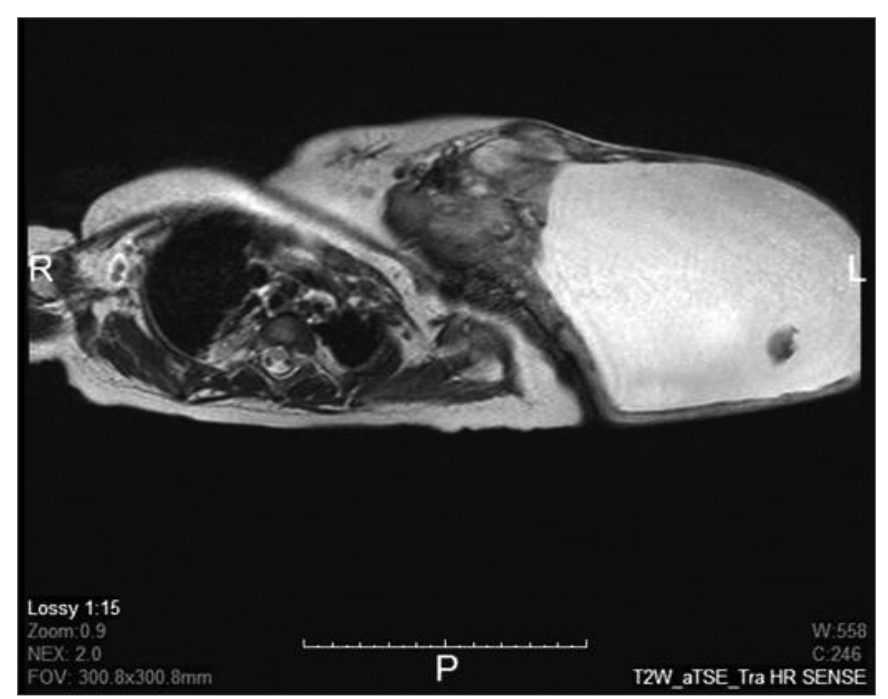

Figure 1: T2-weighted MRI demonstrating a mixed-intensity lesion with mainly fluid component.

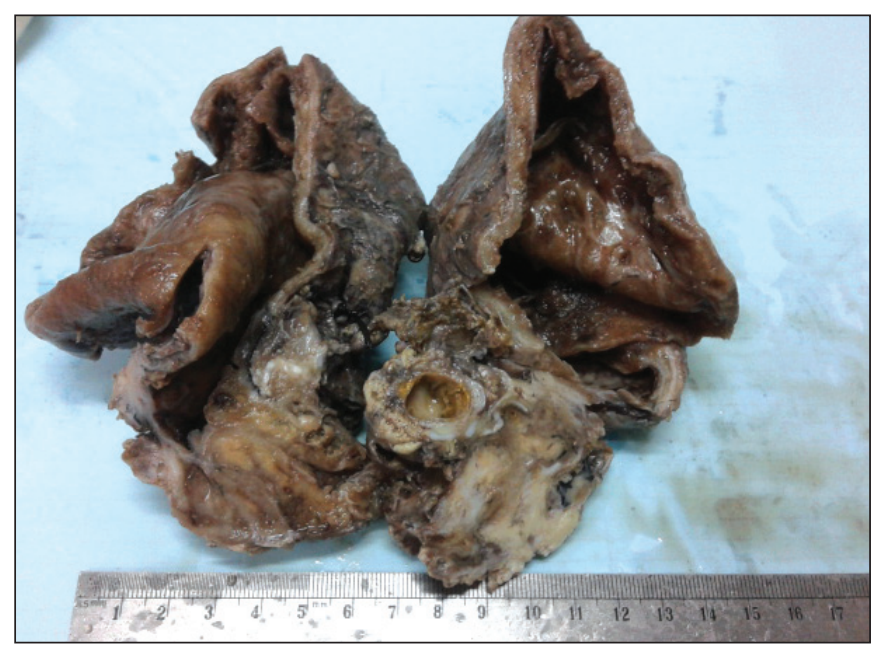

Figure 2: Cystic tumor mass was cut opened to see inner wall. Lower part of the specimen was composed of solid gray white tissue.
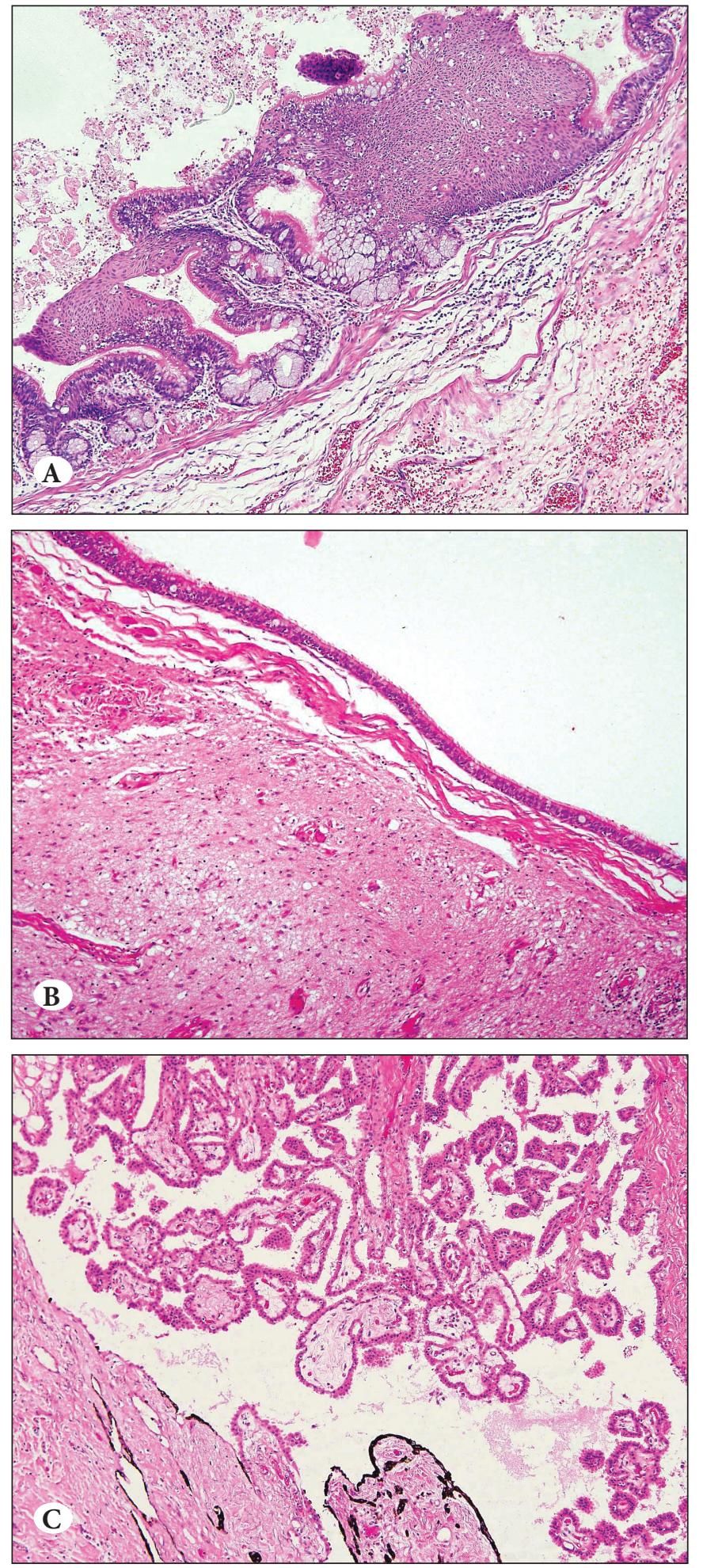

Figure 3: Sections from cystic wall. A) Cyst wall of the tumor was partly lined by squamous epithelium and partly by respiratory typed ciliated epithelium (H\&E x100). B) Cyst wall of the tumor was lined by respiratory typed ciliated epithelium and mature neuroglial tissue beneath the epithelium (H\&E x100). C) Cyst wall of the tumor was partly lined by choroid plexus epithelium in papillary configuration (H\&E x100). 
Histopathologically, the cyst wall was partly lined by stratified squamous epithelium and partly by respiratory typed pseudostratified ciliated columner epithelium (Figure 3A). Subepithelial tissue showed many large foci of mature neuroglial tissue (Figure 3B). Other mature tissue components such as choroid plexus epithelium (Figure 3C), mucus secreting glands, pancreatic acini, salivary glands, adipose tissue, skeletal muscle, bony trabeculae and cartilages were seen in the cyst wall. Most of the solid area was composed of mature neuroglial tissue with astrocytes, oligodendrocytes and numerous psammomatous calcifications (Figure 4A). Foci of mature ependymal cells forming tubules and rosettes were also seen (Figure 4B). Some of the foci of cartilages showed immature cartilage without a clear cut margin which accounted for less than $10 \%$ of sample tissue (Figure $4 \mathrm{C}$ ). However, immature neuroglial tissue components were not seen. Sections from one enlarged cervical lymph node showed foci of mature neroglial tissue within a lymphoid architecture. Based on the above histopathological features, the cystic mass was diagnosed as mature teratoma (Grade 1) and the cervical lymph node was diagnosed as nodal gliomatosis.

\section{DISCUSSION}

Teratomas of the head and neck are interesting because of their obscure origin, bizarre microscopic appearance, unpredictable behavior and often dramatic clinical presentation (5). Cervical teratomas are uncommon. Until 2009, only 217 cases of cervical teratomas have been reported in the world literature and ninety percent of the cases are diagnosed in the pediatric population (6). In the vast majority of cases, the tumour presents clinically as a large neck mass noted at birth (4). Most of the cases present as midline mass and rarely appear in the lateral region (7). Ninety percent of cervical teratomas are diagnosed in the pediatric population; however, a minority can be seen in adults (8). In our case, the mass was diagnosed since fetal life and it presented as a lateral neck mass. The majority of cervical teratomas presenting in infancy and early childhood are mature in nature and exhibit benign clinical behavior; whereas those presenting after the first decade of life exhibit malignant behavior (9). In a study of 65 cases of childhood teratomas under 7 years of age, cervical teratomas made up only 4 cases with three mature and one immature case (10). Most of the congenital cervical teratomas can be diagnosed by antenatal ultrasound (11); however, cystic hygroma is the most common mimicker (4), as in our case.

Approximately one third of the reported cervical teratomas complicate maternal hydramnios (12). However, there was no maternal hydramnios in this case although the mother had history of gestational diabetes.
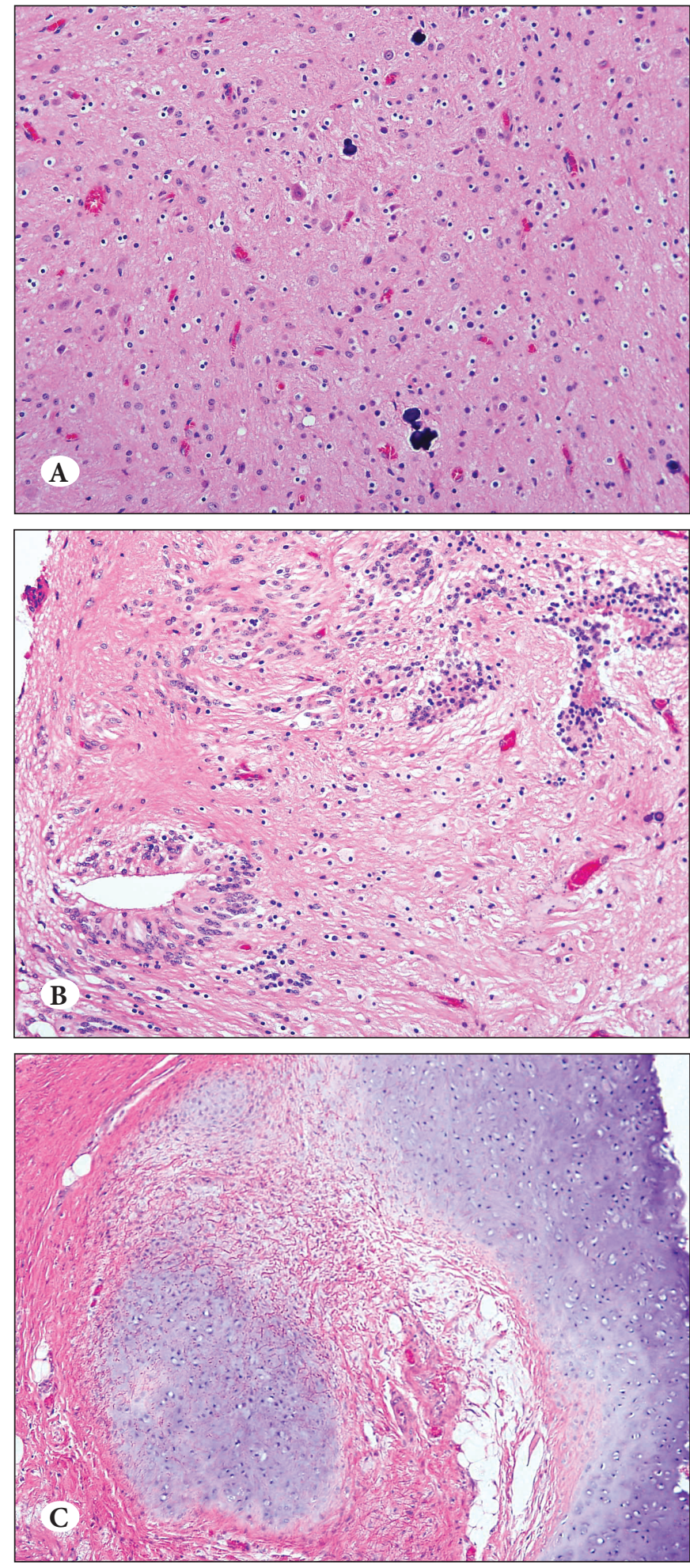

Figure 4: Sections from solid area. A) Foci of mature neuroglial tissue composed of oligodendrocyts and psammomatous calcification (H\&E x200). B) Foci of mature ependymal cells in neuroectodermal area forming tubules and rosettes (H\&E x200). C) Foci of immature cartilage without clear cut boundaries (H\&E $\mathrm{x} 100)$. 
Pathologically, teratomas have heterogeneous histological characteristics. Mature teratomas may contain all manners of adult tissues with varying degrees of organoid development, whereas immature lesions may produce embryonic or extra embryonic fetal tissue (4). Up to $90 \%$ of childhood teratomas contain derivatives from all three embryonic germ layers. $20-40 \%$ contain some immature tissues. In childhood, $75-85 \%$ of teratomas of the head and neck region usually contain neuroectodermal elements (both mature and immature) (6). Mature neuroectodermal tissue such as cerebellum, ependymal tubules, pituitary and retina can be seen in mature teratoma and it does not result misclassification as an immature teratoma (13). Ependymal rosettes should not be mistaken for the primitive rosettes seen in an immature teratoma. The cells lining ependymal rosettes have ample cytoplasm, the nuclei form only one or two layers, and mitotic figures are not present (14). In this case, foci of ependymal cells forming tubules and vague rosettes were also seen.

Grading and classification of both gonadal and extragonadal teratomas are important for the management and sometimes challenging for the anatomic pathologist. Teratomas are generally classified into four grades according to the Gonzalez-Crussi grading system (4). Grade (0): all component tissues appear well differentiated, grade (1): occasional microscopic foci contain incompletely differentiated tissues but not exceeding $10 \%$ of the sampled tissue, grade (2): Immature tissue composed of 10-50\% of sampled tissue, and grade (3): more than $50 \%$ of sampled tissue are composed of undifferentiated tissue. Both grade (0) and (1) are considered as mature teratoma and both grade (2) and (3) are considered immature teratoma (4). Our case contained foci of incompletely differentiated immature cartilage which accounted less than $10 \%$ of all sampled tissue; we therefore decided the case was mature teratoma, grade (1). All teratomas that contain areas of germ cell tumour, non-germ cell malignant tumour and immature teratoma with metastasis are considered malignant teratoma (4). Most of the gynaecological literatures for ovarian teratoma put grade (1) teratoma under immature teratoma (15).

In this case, the striking feature was presence of large multiple foci of mature neuroglial tissue consisting of astrocytes, oligodendrocytes, neuron, microglia, ependymal cells and even multiple foci of psammomatous calcification. Most of the foci of glial tissue were hypercellular like a glial tumour. However, they did not exhibit any pleomorphism or mitosis. Foci of mature neuroglial tissue were also seen in section of cervical lymph node adjacent to the tumour that was diagnosed as nodal gliomatosis. Nodal gliomatosis is not indicative of malignant biological behavior and appears to have the same prognostic significance as gliomatosis peritonei in mature ovarian teratoma (16). In this case, it is possible that previous sclerotherapy caused extraction of neuroglial tissue from cystic teratoma and implantation in the nearby cervical lymph node resulting in nodal gliomatosis.

In conclusion, most of the congenital head and neck teratomas are benign and mature in nature with a good prognosis. Teratoma should be in the list of differential diagnosis for congenital lesions presenting as a neck mass. An ample amount of neuroectodermal tissue including ependymal rosettes should not be mistaken as immature elements.

\section{REFERENCES}

1. Stricker TP, Kumar V. Neoplasia. In: Abbas AK, Fausto N, Ster JC, editors. Robbins and Cotran pathologic basis of disease, 8th ed. Philadelphia (PA): Elsevier Saunders; 2010. 295-6.

2. Gnepp DR. Teratoid neoplasms of the head and neck In: Barnes L, editor. Surgical pathology of the head and neck. New York: Marcel Dekker; 1985. 1411- 33.

3. Shah FA, Raghuram K, Suriyakumar G, Dave AN, Patel VB. Congenital teratoma of nasopharynx. Ind J Radiol Imag. 2002; 12: 201-2.

4. Gonzalez-Crussi F. Teratomas of the neck. In: Extragonadal teratomas. Atlas of tumor pathology, Second Series, Fascicle 18, Washington DC: Armed Forces Institute of Pathology; 1982. 11827.

5. Jain RR, Rabb MF. The difficult pediatric airway. In: Hagberg C, editor. Benumof and Hagberg's airway management. 3rd ed, Philadelphia: Elsevier; 2013. 723-60.

6. Shah A, Latoo S, Ahmed I, Malik AH. Head and neck teratomas. J Maxillofac Oral Surg. 2009; 8:60-3.

7. Görür K, Talas DU, Ozcan C. An unusual presentation of neck dermoid cyst. Eur Arch Otorhinolaryngol. 2005; 262:353-5.

8. Jordan RB, Gauderer MW. Cervical teratomas: An analysis, literature review and proposed classification. J Pediatr Surg. 1988; 23:583-91

9. Rothschild MA, Catalano P, Urken M, Brandwein M, Som P, Norton K, et al. Evaluation and management of congenital cervical teratoma. Arch Otolaryngol Head Neck Surg. 1994; 120:444-8.

10. Basu AK, Chatterjee SK. Teratoma in children under 7 years of age: Analysis of 65 cases. Pediatr Surg Int. 1989; 4:199-201.

11. Norberto HS, Fernandez LT, Ivan JAG, Juan Mario TL. Giant congenital cervical teratoma: Diagnosis, management and long-term follow-up. Donald School Journal of Ultrasound in Obstetrics and Gynecology. 2007; 1:80-5.

12. Rosenfeld CR, Coln CD, Duenhoelter JH. Fetal cervical teratoma as a cause of polyhydramnios. Pediatrics. 1979; 64: 176-9. 
13. Reichert RA. Pathology of ovarian tumors. In: Diagnostic gynecologic and obstetric pathology: An atlas and text. Philadelphia: Lippincott Williams \& Wilkins; 2012. 370-509.

14. Zaloudek CJ. Pathology of germ cell tumors. In: Soslow RA, Tornos C, editors. Diagnostic pathology of ovarian tumors. New York: Springer; 2011. 155-192

15. Talerman A, Vang R. Germ cell tumors of the ovary. In: Blaustein's pathology of the female genital tract. 6th ed. New York: Springer; 2011. 847-908.

16. Dehner LP. Congenital anomalies of the head and neck. In: Pilch BZ, editor. Head and neck surgical pathology. 1st ed. Philadelphia: Lippincott Williams \& Wilkins; 2001. 1-33. 